\title{
In Vitro Test of Anticalculi Effect from Ethyl Acetate Fraction of Chives Leaf (Allium schoenoprasum L.)
}

\author{
Siti Morin Sinaga ${ }^{1}$ Iksen ${ }^{2 *}, K_{e v i n}^{1}$, and Marshinta Romarta Uly \\ Hutabalian ${ }^{1}$ \\ ${ }^{1}$ Department of Pharmaceutical Chemistry, Faculty of Pharmacy, Universitas Sumatera Utara, Medan \\ 20155, Indonesia \\ ${ }^{2}$ Department of Pharmacy, Sekolah Tinggi Ilmu Kesehatan Senior Medan, Medan 20141, Indonesia
}

\begin{abstract}
The purpose of this study was to analyze the ability of chives leaves of ethyl acetate fraction to dissolve calcium in human kidney stones. This research starts from making the ethyl acetate fraction, calibration curve for calcium and measuring dissolved calcium levels in kidney stones by using atomic absorption spectrophotometry. The results showed that the ethyl acetate fraction with a concentration of $2.5 \%$ had the greatest anticalculi capability of $92.02 \%$. The conclusion of this study is that the ethyl acetate fraction of chives leaf has the potential to be anticalculi in the treatment of kidney stones.
\end{abstract}

Keyword: Chives, Atomic absorption spectrophotometry, Anticalculi, In vitro

\begin{abstract}
Abstrak. Tujuan dari penelitian ini adalah untuk menganalisis kemampuan fraksi etil asetat daun kucai untuk melarutkan kalsium pada batu ginjal manusia. Penelitian ini dimulai dari pembuatan fraksi etil asetat, pembuatan kurva kalibrasi kalsium serta pengukuran kadar kalsium terlarut pada batu ginjal dengan menggunakan spektrofotometri serapan atom. Hasil penelitian menunjukkan bahwa fraksi etil asetat dengan konsentrasi 2,5\% memiliki kemampuan antikalkuli yang terbesar yakni 92,02\%. Kesimpulan penelitian ini adalah bahwa fraksi etil asetat daun kucai berpotensi sebagai antikalkuli pada pengobatan batu ginjal.
\end{abstract}

Kata Kunci: Kucai, Spektrofotometri serapan atom, Antikalkuli, In vitro

Received 30 November 2019 | Revised 16 December 2019| Accepted 19 December 2019

\section{Introduction}

Kidney stones are one of the most common diseases in the kidney. Generally, kidney stones occur because the body lacks fluids so that there is a blockage in the channel from the kidneys to the bladder. The stones in the kidneys are formed from chemicals that are usually present in urine such as calcium, uric acid, phosphate and other chemicals [1], [2]. One of the medicinal plants that are widely used people in Indonesia is Chives (Allium schoenoprasum L.). Chives many health benefits such as overcome vaginal discharge, constipation and and antimicrobial. In addition, chives are also efficacious improving blood flow and prevent blood clots. Chives

\footnotetext{
*Corresponding author at: Department of Pharmacy, Sekolah Tinggi Ilmu Kesehatan Senior Medan, Medan 20141, Indonesia

E-mail address: ikseniksen08@gmail.com
} 
leaves contain various phytochemical compounds including alkaloids, flavonoids, glycosides, steroids, tannins and various minerals such as potassium, calcium, magnesium and sodium [3]. Previous studies have shown that infuse and extracts (ethanol and ethyl acetate) of chives leaves have anticalculi activity [4], [5], [6], [7]. Therefore, this study aims to examine the continuation of anticalculi effect using the ethyl acetate fraction of chives leaf to help the treatment of kidney stones by using traditional medicine.

\section{Materials and Methods}

\subsection{Materials}

Materials used in this research were chives (Allium schoenoprasum L.) leaves (obtained from Pasar Baru, Perbaugan regency, North Sumatera, Indonesia), human kidney stones (obtained from Permata Bunda Hospital, Medan), nitirc acid 65\% (Merck), demineralizd water (Brataco), standard solution of calcium (BOECO), ethanol (Merck), and ethyl acetate (Merck). The instrument used were Atomic absorption spectrophotometry (Hitachi Zeeman-2000) with airacytylene gas and cathode lamp of calcium. Chives leaf was identified at Herbarium Medanense (Universitas Sumatera Utara Number 928/MEDA/2017).

\subsection{Preparation of Ethyl Acetate Fraction of Chives Leaves}

$40 \mathrm{~g}$ of chives leaf ethanol extract was fractioned using ethyl acetate solvent, homogenized and partitioned by using separatory funnel. Then the ethyl acetate fraction were concentrated with a rotary evaporator at $50^{\circ} \mathrm{C}[8]$.

\subsection{Research Design}

In vitro anticalculi effect of the ethyl acetate fraction of chives leaves divided into 6 groups 1\% without and with incubation with human kidney stones, $2.5 \%$ without and with incubation with human kidney stones, $5 \%$ without and with incubation with human kidney stones. All of these groups (50 $\mathrm{ml}$ for each group) will be added with $50 \mathrm{mg}$ of human kidney stones and then incubated at $37^{\circ} \mathrm{C}$ for 4 hours.

\subsection{Quantitative Analysis by Using Atomic Absorption Spectrophotometry}

Before the quantitative analysis, all the sample preparation were added by $10 \mathrm{~mL}$ of nitric acid $65 \%$ and heat on hotplate until the solution become tranpicious. After this, the calcium level from each groups were measured by using atomic absroption spectrophotometry. The absorbance value of calcium should be within the range of standard calcium calibration curve $(0.2 ; 0,4 ; 0.6 ; 0.8$ and $1 \mathrm{ppm})$ at $422.7 \mathrm{~nm}$ wavelenght [4], [9]. Calcium values were expressed as mean $\pm \mathrm{SD}$ with six replicates measurements. 


\section{Results and Discussions}

\subsection{Calibration Curve of Calcium}

Calcium calibration curves were obtained by measuring the absrobance of standar solutions at wavelenght of $422.7 \mathrm{~nm}$ for calcium. From the calibration curve measurements (Figure 1), the regression $\mathrm{Y}=0.101443 \mathrm{X}+0.000795$ was obtained. The calcium correlation cofficient obtained could be accepted according to Harmita (2004) and Putra et al (2018) [10], [11], [12].

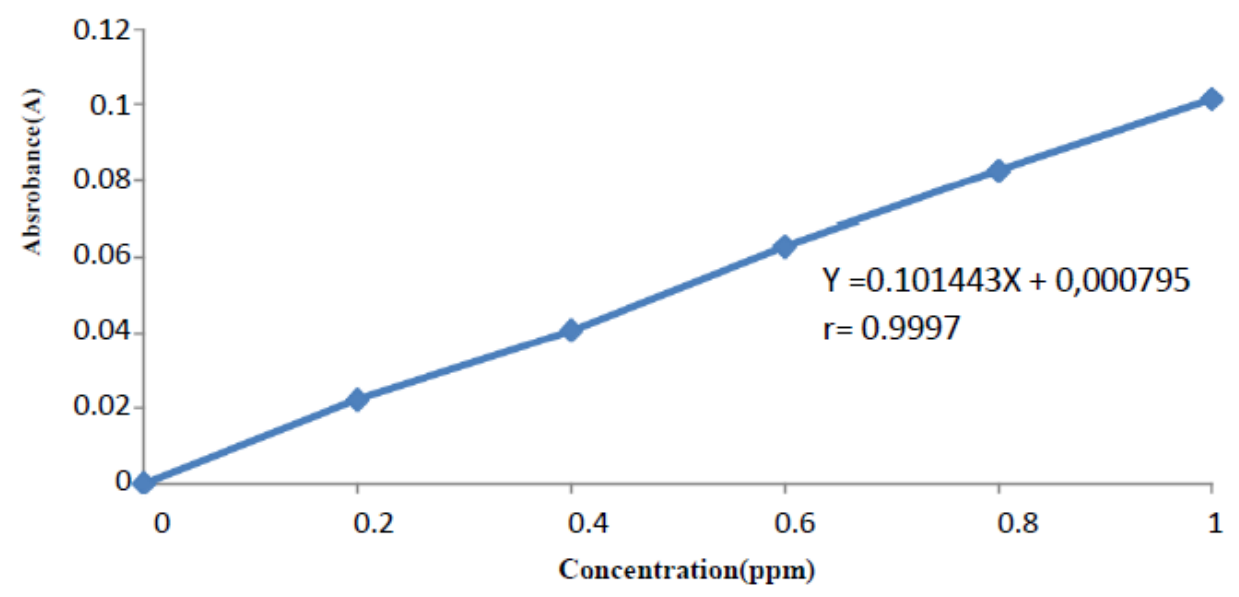

Figure 1. Calibration curve of calcium

\subsection{In Vitro Anticalculi Effect}

In vitro anticalculi testing was using chives leaves ethyl acetate fraction was aimed to determine the solubility of calcium in human kidney stones. The level of calcium solubility in fraction solution is presented in Table 1 . Based on Table 1 it can be seen that the higher the concentration of ethyl acetate fraction, the calcium concentration will increase as well. The highest percentage of calcium solubility is at concentration of $2.5 \%$ while at the concentration of $5 \%$ there is a decrease in the calcium solubility of kidney stones.

Table 1. In vitro anticalculi result

\begin{tabular}{ccccc}
\hline Concentration & $\begin{array}{c}\text { Calcium } \\
\text { Level Before } \\
\text { Incubation } \\
(\mathbf{p p m})\end{array}$ & $\begin{array}{c}\text { Calcium Level } \\
\text { After } \\
\text { Incubation } \\
(\mathbf{p p m})\end{array}$ & $\begin{array}{c}\text { Level of } \\
\text { Dissolved } \\
\text { Calcium }(\mathbf{p p m})\end{array}$ & $\begin{array}{c}\text { Percentage of } \\
\text { Calcium } \\
\text { Solubility (\%) }\end{array}$ \\
\hline $1 \%$ & $1.8176 \pm 0.0351$ & $20.7120 \pm 0.0351$ & 18.89 & 91.22 \\
$2.5 \%$ & $2.8510 \pm 0.0239$ & $35.7204 \pm 0.0351$ & 32.87 & 92.02 \\
$5 \%$ & $3.7448 \pm 0.0464$ & $29.9125 \pm 0.0351$ & 26.17 & 87.48 \\
\hline
\end{tabular}

The ability to dissolve kidney stone calcium is caused by the extracts which have important roles in calcium solubility in kidney stones such as flavonoids, potassium compounds and the acidity $(\mathrm{pH})$ of the extract. The formation of calcium in kidney stones is inhibited by flavonoids, potassium, alkaloids and citric acid. Flavonoid compounds contained in the extract are important factors in the calcium solubility of kidney stones. This is because the carboxylic 
hydroxyl groups of flavonoid compounds react with calcium in kidney stones to form $\mathrm{Ca}$ flavonoid chelate complexes that are easily soluble in water [13].

\section{Conclusion}

Chives leaves ethyl acetate fraction solution showing a potential anticalculi effect. The results of this study are in line with previous studies in which infuse and extract had anticalculi activity.

\section{Acknowledgement}

The authors are gratefully thank to Faculty of Pharmacy Universitas Sumatera Utara and Sekolah Tinggi Ilmu Kesehatan Senior Medan for providing the facilities.

\section{REFERENCES}

[1] American Urology Guideline. Assessed online November 30 $30^{\text {th }}$ 2019. Available from: https://www.auanet.org/guidelines

[2] A.I. Muhgni, Uji Aktivitas ekstrak etanol 70\% kulit batang kapuk randu (Ceiba pentandra (L.) Gaertn) sebagai penghambat batu ginjal pada tikus putih jantan. Jakarta: UIN Syarif Hidayatullah, 2013.

[3] A.E. Al-Snafi, "Pharmacological effects of Allium species grown in Iraq", International Journal of Pharmaceuticals and Health Care Research, vol. 1, no. 4, pp. 132-55. 2014.

[4] I. Iksen, G. Haro, amd S.M. Sinaga, "In vitro test of chives leaves infuse on calcium oxalate solubility using atomic absorption spectrophotometry", International Journal of ChemTech Research, vol. 10, no. 2, pp.099-102. 2017.

[5] G. Haro, S.M. Sinaga, I. Iksen, N. Nerdy, and S. Theerachetmongkol, "Protective effects of Chives leaves (Allium schoenoprasum L.) infusion against ethylene glycol and ammonium chloride induced nephrolithiasis in rats", Journal of Applied Pharmaceutical Sciences, vol. 7, no. 8, pp. 222-5. 2017.

[6] S.M. Sinaga, I. Iksen, G. Haro, and S. Wardhany, "Potency of chives (Allium schoenoprasum L.) leaves infuse as inhibitor calcium lithogenesis on urinary tract", Asian Journal of Pharmaceutical and Clinical Sciences, vol. 11, no. 3, pp. 77-80. 2018.

[7] S.M. Sinaga, S. Sudarmi, I. Iksen, K. Kevin, and M.P. Sari, "Evaluation of total phenolic, flavonoid content, antioxidant and in vitro antilithogenesis activities of chives leaf", Rasayan Journal of Chemistry, vol. 11, no. 4, pp. 1604-8. 2018.

[8] D. Pertiwi, I. Hafiz, and R. Salma," Antibacterial activity of gel of ethanol extract of papaya leaves (Carica papaya L.) against Propionobacterium acne", Indonesian Journal of Pharmaceutical and Clinical Research, vol. 2, no. 1, pp. 1-6. 2019

[9] I.G. Gandjar, and A. Rohman ( ${ }^{\text {st }}$ Edition), Pharmaceutical Chemistry Analysis, 1st ed., Pustaka Pelajar, Yogyakarta, 2007.

[10] H. Harmita, "Petunjuk pelaksanaan validasi metode dan cara perhitungannya," Majalah Ilmu Farmasi, vol. 1, no. 3, pp.117-30. 2004.

[11] E.D.L. Putra, N. Ginting, N. Nazliniwaty, I. Iksen, E. Kurniawan, and N. Nerdy, " In vitro antinephrolithiasis effect of breadfruit (Artocarpus altilis (Park.) Fosberg) leaves extract by atomic absorption spectrophotometry", Asian Journal of Pharmaceutical and Clinical Sciences, vol. 11, Special Issue 1, pp. 206-9. 2018.

[12] G. Haro, I. Iksen, R.M. Rumanti, N. Marbun, R.P. Sari, and R.P.J. Gultom, "Evaluation of antioxidant activity and minerals value from watercress (Nasturtium officinale R.Br.)", Rasayan Journal of Chemistry, vol. 11, no. 1, pp. 232-7. 2018.

[13] W. Winarti, S. Nuryanti, and I. Said," Pengaruh konsentrasi ekstrak tanaman meniran (Phillanthus ninuri L.) dalam melarutkan kalsium", Jurnal Akademika Kimia, vol. 3, no. 4, pp. 214-21. 2014. 